\title{
Smokestacks and Pipelines: Russian-Turkish Relations and the Persistence of Economic Development
}

When Aleksei Kosygin visited Turkey in 1975 for the inaugural firing of a massive Soviet-built steelworks, he laid out an ideologically charged vision of development: "unlike the Americans with their Coca-Cola factories, we contribute to industrialization." "The Soviet chairman of the council of ministers picked an unusual audience for his disparagement of the United States. Even though Washington had recently imposed an arms embargo in response to Ankara's intervention on Cyprus, Turkey was still a NATO member. More to the point, Turkey had been a key recipient of U.S. aid since the beginning of the Cold War. ${ }^{2}$ The Soviet Union could not truly compete with the Western investments that included a Coca-Cola plant which opened in Istanbul in I964, but Moscow nevertheless committed extensive resources to industrial sites in Anatolia in the I960s and I970s. Given that Turkey was closer to the Transatlantic Alliance than the Non-Aligned Movement, the Soviet challenge to U.S.-led modernization in Turkey is an unusual and thus revealing place to find what looks like Cold War competition to develop the Global South.

Outright hostility between the Soviet Union and Turkey at the end of the Second World War has led historians to overlook ample evidence of cooperation and treat the two states as implacable foes. ${ }^{3}$ But the industrialization that Kosygin lauded fits readily into a larger story of Soviet interactions with the Third World. ${ }^{4}$ Beginning in the I95os, Ankara sought to expand trade with its

${ }^{*}$ We would like to thank Derek Hirst, Marc Hoffman, Oscar Sanchez-Sibony, Eliza Gheorghe, Chris Miller, and the anonymous reviewers and editors at Diplomatic History for criticisms and suggestions that significantly improved this article.

I. "İskenderun Demir-Çelik Törenle Açıldı," Cumburiyet, December 29, I975; "Demirel ve Kosigin, İsdemir'i Hizmete Açtı," Milliyet, December 29, 1975.

2. Nathan J. Citino, Envisioning the Arab Future: Modernization in U.S.-Arab Relations, 19451967 (Cambridge, 2017); Begüm Adalet, Hotels and Highways: The Construction of Modernization Theory in Cold War Turkey (Stanford, CA, 2018).

3. See the cursory treatment of interwar cooperation in Zara Steiner, The Lights that Failed: European International History, I9I9-1933 (Oxford, 2007), 534; see Turkey's absence in the Soviet-related chapters in Stephen J. Macekura and Erez Manela, ed., The Development Century: A Global History (Cambridge, 2018).

4. Nick Cullather, "Research Note: Development? It's History," Diplomatic History 24, no. 4 (2000): 64I-653; David C. Engerman, "The Romance of Economic Development and New Histories of the Cold War," Diplomatic History 28, no. I (2004): 23-54; Odd Arne Westad, The

Diplomatic History, Vol. 44, No. 5 (2020). @ The Author(s) 2020. Published by Oxford University Press on behalf of the Society for Historians of American Foreign Relations. All rights reserved. For permissions, please e-mail: journals.permissions@oup.com. doi:Io.Io93/dh/dhaao46

Advance Access Publication on June 28, 2020 
northern neighbor at a point when Moscow was just beginning to court postcolonial countries and encourage their governments to use trade with the Soviet Union to complement or balance exchanges with the West. Like their Indonesian counterparts, and at the same time, Ankara's leaders appreciated the Soviet preference for state-controlled clearing agreements that offered industrial exports without demanding hard currency in return. ${ }^{5}$ Interactions that began with trade quickly grew to include Soviet support for Turkey's statist industrialization, much as Moscow's support reinforced statist economic models throughout the Third World. ${ }^{6}$ While Turkish politicians drew lessons from Soviet methods, they also built on a longer tradition of statist politics at home. Statist economic thought had emerged already in the last years of the Ottoman Empire and provided a basis for Soviet-Turkish interactions as early as the I930s. ${ }^{7}$

In fact, exchanges that seem typical of Cold War development have characterized Russian-Turkish exchanges for much of the past century. ${ }^{8}$ Long before the Soviet Union and the United States engaged in direct competition in the Global South, Moscow extended aid because Turkish revolutionaries, like their Russian counterparts, were facing the consequences of rejecting the terms of the post-First World War order. Between I920 and I922, Soviet military and financial assistance helped Turkish forces defeat European occupying armies. By the I930s, Moscow was able to send equipment and engineers to build two textile factories that were the centerpieces of a Turkish five-year plan-the first Soviet-advised plan voluntarily adopted by a foreign state. The tensions unleashed by the Second World War have never been fully put to rest, but within a decade of the war's end Moscow and Ankara began to temper political conflict in the name of economic cooperation. At the height of the Cold War and despite membership in opposing blocs, Moscow revived the earlier

Global Cold War: Third World Interventions and the Making of Our Times (Cambridge, 2007); Cyrus Schayegh, "Iran's Karaj Dam Affair: Emerging Mass Consumerism, the Politics of Promise, and the Cold War in the Third World," Comparative Studies in Society and History 54, no. 3 (2OI 2): 6I 2-643; Timothy Nunan, Humanitarian Invasion: Global Development in Cold War Afghanistan (Cambridge, 2016); David C. Engerman, "Development Politics and the Cold War," Diplomatic History 4I, no. I (2017): I-I9; David C. Engerman, The Price of Aid: The Economic Cold War in India (Cambridge, MA, 2018).

5. Oscar Sanchez-Sibony, Red Globalization: The Political Economy of the Soviet Cold War from Stalin to Khrushchev (Cambridge, 2016), chap. 4, esp. I42-I 45 .

6. Westad, The Global Cold War, 92; Alessandro Iandolo, "The Rise and Fall of the 'Soviet Model of Development' in West Africa, 1957-1964," Cold War History I 2, no. 4 (2012): 683704; Artemy M. Kalinovsky, Laboratory of Socialist Development: Cold War Politics and Decolonization in Soviet Tajikistan (Ithaca, NY, 2018).

7. See Samuel J. Hirst, "Anti-Westernism on the European Periphery: The Meaning of Soviet-Turkish Convergence," Slavic Review 72, no. I (Spring 2013): 32-53.

8. Many works acknowledge the earlier origins of Cold War development but still frame development as a story that is fundamentally about the Cold War. See Odd Arne Westad, The Cold War: A World History (New York, 20I 7); Timothy Nunan, "Graveyard of Development? Afghanistan's Cold War Encounters with International Development and Humanitarianism," in The Development Century, ed. Macekura and Manela, 220-239. 
commitment to industrialize Turkey—this was the context for Kosygin's visit. Amidst the turbulence of the I980s and I990s, both states curtailed investments in heavy industry but created a new interdependence with gas pipelines across the Black Sea. Then, beginning in the 200os, two centralizing states again began to produce joint construction projects. Soviet aid thus arrived in Turkey long before the Cold War and interstate cooperation in the name of development survived the collapse of the Soviet Union.

This article argues that the pursuit of parity with the West has made economic ties the defining feature of Russian-Turkish relations across the past century. What "the West" meant often differed in the Soviet Union and in Turkey and these meanings changed over time, but elites in both countries have generally seen themselves in a tense relationship with a trans-Atlantic collective whose decisions have been made in London, Paris, and Washington. Joint exclusion from the Western international order was clearest after the First World War because Moscow and Ankara had to fight nearly simultaneously against Western-led interventions to create new capitals from the rubble of failed empires. After each had defeated their foreign opponents, Russian and Turkish revolutionaries consistently pursued the industrial and technological achievements that defined Western power and whose absence both saw as part of the reason for the collapse of their imperial predecessors. Because politicians in Moscow and Ankara have long been convinced of Western superiority, they have not prioritized bilateral ties that might jeopardize more important relations with the West. They have, however, harnessed mutual interactions to the drive for development. Even when Turkey was a NATO member, a significant segment of the Turkish political elite chafed at Turkey's subordinate role in the alliance. Prime ministers from across the Turkish political spectrum met with Soviet leaders to coordinate the use of state power to increase bilateral exchange. These dealings rarely trumped diplomacy and the most intense cooperation coincided with periods when both states had broader reasons to resent the West. The proximity of Kosygin's visit to the Turkish intervention on Cyprus was no coincidence but neither was it the full story. The scope of one hundred years reveals persistent and politicized economic interactions.

State intervention in the economic sphere has been a common and prominent feature of Russian and Turkish politics and it has shaped convergence. The Bolsheviks saw tsarist Russia's backwardness as a result of its participation in an exploitative imperialist order and offered Turkey a novel system of collaboration. Necessary imports of technology and goods from the West required hard currency and the Bolsheviks argued that non-Western states should actively coordinate areas of mutually beneficial exchange based on local resources. Turkey would have preferred more advanced Western factories in the I930s and the r 960 s, but the Soviet Union offered passable alternatives on terms calculated to bypass international markets and soothe Turkey's anxieties. Soviet leaders spoke loudly of their sympathy for Turkey's dependence on Western 
finance and found themselves obliged to accept payment for factories in Turkish agricultural exports.

The motives that shaped joint ideological pronouncements were compatible despite their differences. Moscow sometimes made concessions for strategic advantage but also held broader hopes for Turkey. Soviet observers rarely thought Turkey might become a socialist ally, but they defined independence from the West as a goal in and of itself. Ankara's politicians generally pursued Soviet contracts for pragmatic rather than ideological reasons, but they often shared in the anti-Western sentiment that was more visible in Moscow.

Development, in its Cold War sense, was a short-lived phenomenon. At the height of the Cold War, Soviet, U.S., and Third World leaders found a common language in their desire to transform societies and improve the human condition. ${ }^{9}$ Disillusionment set in by the r96os and r970s, and the United States moved away from project-based aid. The Soviet Union, however, continued to focus on large industrial plants like the one that Kosygin visited in İskenderun. ${ }^{{ }^{\circ}}$ In opposition to the United States and the West more broadly, Moscow's relations with non-Western states like Turkey have included a long commitment to address economic weakness in relative terms. Much of the historical work on development prioritizes the Cold War years and relegates phenomena outside that period to the role of precursors and epilogues. The long arc of cooperation with Turkey demonstrates that the drive to catch up with the West fed the Soviet development politics of the Cold War but was not subsumed by them.

Accounts of Russian-Turkish relations that repeat an almost-obligatory opening reference to wars between the Ottomans and the Romanovs have focused our attention on moments of friction. ${ }^{\text {I }}{ }^{2}$ Without question, the two states have competing interests and divergent security concerns. The struggle to control the narrow Straits that connect the Black and Mediterranean Seas has divided the two countries, but Moscow and Ankara have also clashed as they drew on their respective imperial connections to project power in various parts of Eurasia. ${ }^{\mathrm{I}}$ At moments when shared frustration with the transatlantic Western order receded, as in the I940s and the late I980s, contestation of sites in Southeastern Europe, the Caucasus, and Central Asia intensified. When the interwar Soviet-Turkish partnership against the West broke down in the

9. Kalinovsky, Laboratory of Socialist Development, 4-5.

Io. Engerman, The Price of Aid, 274.

I I. Bruce R. Kuniholm, The Origins of the Cold War in the Near East: Great Power Conflict and Diplomacy in Iran, Turkey, and Greece (Princeton, NJ, I980), 6; Vladislav Zubok, A Failed Empire: The Soviet Union in the Cold War from Stalin to Gorbachev (Chapel Hill, NC, 2009), ${ }_{3} 6$.

I2. For a helpful reading of Russo-Ottoman clashes in the Caucasus that emphasizes security rather than ideology, see: Michael A. Reynolds, "Buffers, not Brethren: Young Turk Military Policy in the First World War and the Myth of Panturanism," Past and Present 203, no. I (2009): I 37-I 79; see also Michael A. Reynolds, Shattering Empires: The Clash and Collapse of the Ottoman and Russian Empires, I9o8-19I8 (Cambridge, 20I I). 
Second World War, Moscow's demands for control of the Straits and territory in eastern Anatolia drove Turkey into NATO and a decidedly pro-Western stance. Yet unlike their imperial forebears, the states that reconstituted themselves around new capitals in Moscow and Ankara have never fought against each other. A narrative that begins with the radical break of the First World War must explain the management of conflict and not conflict itself.

The relationship that Bolsheviks and Kemalists forged in the aftermath of the First World War was both more and less than a formal alliance. A sense of shared insecurity carried through into the I930s, when Soviet and Turkish diplomats discussed the possibility of a Soviet naval base in Izmir to help protect the Straits. ${ }^{13}$ The latter project never materialized, and neither side was ever prepared to sign a military agreement-because of both residual distrust and fear that alliance would impair relations with the Western governments that controlled access to the international markets that both Moscow and Ankara needed to rebuild their countries after the war. Nonetheless, the two sides worked together in ways that surpassed what might be expected from pragmatic allies. Indeed, the tools of economic nationalism united them. ${ }^{{ }^{4}}$ Already in the I920s, when much of the world was still focused on the gold standard and fiscal conservatism, the Soviet Union and Turkey adopted measures akin to the clearing agreements that were typical of the statism of the r 93 os. Moscow and Ankara possessed an early and shared conviction that state action was necessary to foster the development that would allow them to move up in the hierarchy of the international order.

The violence that continued in the East long after the negotiations of the Paris Peace Conference played a crucial role in forming the anti-Western thrust of early Soviet-Turkish connections. Just three days after Mustafa Kemal Pasha-yet to take the name Atatür-made Ankara the headquarters of the Turkish national struggle in April I920, his first message abroad was to Moscow. ${ }^{15}$ Europe had traditionally been a source of support against Russian encroachment in the context of Ottoman weakness, but Mustafa Kemal reversed centuries of foreign policy after İstanbul and Anatolia were occupied by European armies. For their part, the Bolsheviks saw Turkey as part of an oppressed East in which they could partner with revolutionary nationalists against imperialism. Despite the burdens of Soviet Russia's own civil war, Moscow provided enough gold to cover Ankara's budget for an entire year and a quarter of the rifles and half of the ammunition used in the Turkish War of Independence. ${ }^{16}$ When Moscow and Ankara signed their first diplomatic

I3. Dokumenty vneshnei politiki SSSR, vol. I9 (Moscow, I974): 325-6.

I4. Ivan T. Berend, Decades of Crisis: Central and Eastern Europe before World War II (Berkeley, CA, I998), 234.

I5. Published in Stefanos Yerasimos, Kurtuluş Savaşında Türk-Sovyet İlişkileri, I9I7-1923

(İstanbul, 2000), 223.

I6. Yerasimos, Kurtuluş Savaşında, 6ı 8-6ı 9 . 
agreement in I92 I, the "treaty of friendship and fraternity" began with a declaration of "solidarity in the struggle against imperialism." ${ }^{7}$ Although they did not refer to an alliance here, both sides used the word elsewhere to describe their joint resistance against the West. ${ }^{18}$

Turkey's military successes and the subsequent Lausanne Conference demonstrated the limits faced by all those who have sought to advance a MoscowAnkara axis. The Soviet delegation arrived in Switzerland hoping that the Russo-Turkish understanding reached during the war years was still in force. Ankara, to make headway on its economic and territorial claims, gave ground on the issue about which the Soviets cared most-the Straits. Unrestricted passage through this waterway gave the British navy access to the Black Sea, and Moscow advanced an extreme claim of Turkish sovereignty that would have blocked the thoroughfare to all foreign military ships. The Turks protested to the Soviet delegation that, while they were themselves fighting for sovereignty, concessions were necessary to bring their devastated country peace and revive economic relations with the West. ${ }^{19}$ Turkey could point to the I92 I AngloSoviet trade agreement as evidence that the need for Western finance had forced Moscow itself to compromise less than two years earlier. The West held the keys to acceptance into the postwar international order, and Ankara accepted demilitarization of the Straits and foreign ships' right of passage, along with a cooling of relations with Moscow.

When separate defenses of individual interests in negotiations with the West constrained the initial political alliance, the impetus of Soviet-Turkish relations shifted to the economic sphere. Maritime traffic across the Black Sea had increased after the Anglo-Russian trade agreement broke the embargo against Soviet Russia, but İstanbul was merely a transit port. Soviet exports were shipped on to Western Europe and revenue was used to purchase non-Turkish goods. ${ }^{20}$ Without state intervention, the pull of Western markets circumscribed the possibilities for Soviet-Turkish exchange. As early as 1922, Soviet representatives in Turkey advocated that trade be forced through other Black Sea ports to reach Turkey's Anatolian hinterland. ${ }^{21}$ To that end, Moscow exempted Turkish merchants from the Soviet state monopoly on foreign trade and allowed them to trade in ports like Odessa. The U.S.S.R. accounted for between two and seven percent of Turkey's foreign trade in the interwar period-

I 7. Dokumenty vneshnei politiki SSSR, vol. 3 (Moscow, I959), 597.

I8. Russian State Archive of Social-Political History (hereafter RGASPI), fond 5, opis' I, delo 2262, list 2 I (Intercepted communication. Ali Fuad to Turkish Ministry of Foreign Affairs, April 9, I922). All subsequent citations from Russian archives will abbreviate the location information for the documents cited.

I9. RGASPI, f. I 59, op. 2, d. I9, 1. 5 I (G.V. Chicherin to the Soviet Foreign Commissariat, December 5, I922).

20. Russian State Economic Archive (hereafter RGAE), f. 4I3, op. 2, d. 839, 1. 69.

2 I. RGAE, f. 4I3, op. 2, d. 838, 1.87 (S.I. Aralov to Soviet Commissariat of Foreign Trade, March I, I922). 
Moscow had its own worries and could only absorb so many Turkish agricultural imports-but purchases were calculated to help Turkey avoid total dependence on the West. The Soviet government required documentation that the goods were of Turkish provenance to make sure that profits accrued to the Turkish national economy.

With the trade agreement of 1927 -years before clearing agreements became widespread in the I930s-the two sides pledged that the value of Soviet imports from Turkey would be equal in value to Soviet exports to Turkey. When the Soviet ambassador asked the Turkish foreign minister where the latter's proposal for a "net balance" had come from, the Turkish minister replied that it was a natural product of the two sides' pursuit of shared economic goals rather than individual interests. ${ }^{22}$ The net balance arrangement was worked out in an addendum to the 1927 agreement, kept secret lest other states should demand similar privileges. A new treaty in 1937 reworked the net balance into a now internationally standard formal clearing agreement and this barter arrangement became the basis for economic negotiations during the Cold War. Very early, Moscow and Ankara had worked out a model of exchange that did not involve the hard currency that both needed for their purchases in the West.

The Great Depression shattered Soviet and Turkish hopes of growth through trade with the West, and hence it increased the possibilities for joint development initiatives. Moscow committed to state-driven industrialization before Ankara, but by mid-I930, statism was well on its way to becoming an official Turkish government policy. In 193 I, Mustafa Kemal's Republican People's Party adopted statism as one of its six core principles-alongside and equal to other key terms like nationalism and secularism. The Soviets triumphantly noted that the Turkish prime minister, İsmet Pasha, had proclaimed a new economic course just days before the most prominent Soviet official visit to Turkey since the War of Independence. ${ }^{23}$ Like Jawaharlal Nehru and others who would become leaders in what would become known as the Third World, Turkish politicians in the interwar period found much to admire in Soviet industrialization. ${ }^{24}$ Unlike Nehru, the independence and sovereignty achieved in 1923 allowed Turkish politicians to apply for Soviet aid in the early r93os.

İsmet Pasha used Soviet-Turkish interactions to support his statist arguments at home and traveled to Moscow in 1932 to obtain eight-million-dollars of credit to support Turkey's first five-year plan. ${ }^{25}$ Dollars were used only in

22. Archive of the Foreign Policy of the Russian Federation (hereafter AVP RF), f. 4, op. 39, pap. 242 , d. $53268,1.32$ (Ia.Z. Surits, transcript of a conversation with Tevfik Rüştü, January 27, 1927 ).

23. Ismet took the surname Inönü in 1934 , and will return with that name when this story arrives at the statist exchanges of the ig6os. For Soviet praise for İsmet's statist proclivities, see, for example, AVP RF, f. 5, op. Io, pap. 68, d. I24, 1. 2 (Ia.Z. Surits to L.M. Karakhan, January I, I930).

24. Bidyut Chakrabarty, "Jawaharlal Nehru and Planning, I938-I94I: India at the Crossroads," Modern Asian Studies 26, no. 2 (1992): 275-287; Engerman, The Price of Aid, 2325 . 
the abstract for the sake of denomination, and the Soviet Union sent machinery for the construction of textile plants in the Anatolian cities of Kayseri and Nazilli. Turkey, in turn, paid off the Soviet investment with exports. One Turkish newspaper published the comments of an incredulous İstanbul citizen who remarked, "We should call this barter, not credit." ${ }^{26}$ İsmet confided to the Soviet ambassador that Turkey had turned to Moscow for aid because European offers came with strings that would keep Turkey "an agricultural colony" and only the Soviets' terms allowed for Turkey's industrial transformation. ${ }^{27}$ In 1935, Celal Bayar visited Moscow to ask for a second and larger round of industrial aid, but the Soviet leadership was by then distracted by changes on the European continent. ${ }^{28}$

New threats had overtaken shared fears of the transatlantic West and thus strained the Soviet-Turkish partnership. In Moscow, Hitler's anti-communism and plans for Eastern Europe made Germany seem the greater danger; in Ankara, Italian designs in the Mediterranean were more immediate. As Italy's navy grew, Ankara called in 1936 for renegotiation of the demilitarized regime in the Straits that had been imposed at Lausanne. Moscow protested that in I 923 the Soviet delegation had supported Turkey's rights to fortify the Straits but that Turkey's call for renegotiation now, just a month after Nazi Germany remilitarized the Rhineland, suggested approval of Hitler's revisionist politics. ${ }^{29}$ Ultimately, Moscow joined meetings in Montreux only to be frustrated by Ankara's apparent closeness to London; even as Turkey obtained the right to place armaments along the Straits, the Soviets failed in their long-held wish that the waterway be closed to British warships. As at Lausanne, the two sides fell out over what both considered one of the most pressing geopolitical questions, and yet economic cooperation continued.

The anti-Western understanding that Ankara and Moscow had shared since I 920 was undermined as the Italian threat pushed Turkey towards Britain, but Nazi policies gave new meaning to anti-imperialist economics. Germany's "New Plan," which established an export empire in southeastern Europe and the Middle East, drew Turkey into a German-Turkish trade agreement in 1933. ${ }^{3 \circ}$ Germany had more manufactured goods than the Soviet Union to barter, and in just a couple of years almost half of Turkish exports were destined for the Nazi market. ${ }^{31}$ In 1932 , İsmet had asked the Soviet Union to help

25. İsmet was engaged in "development politics" in the sense that David Engerman uses the term. See Engerman, The Price of Aid, 3.

26. "Halkın Sesi," Son Posta, May ı, I 932.

27. Dokumenty vneshnei politiki SSSR, vol. I 5 (Moscow, I969), 457-458.

28. Turkish Prime Ministerial Archives (hereafter BCA), 30.0.10..200.362.I6 (Turkish Embassy Report on Celal Bayar's meetings in Moscow, August I4, I935).

29. AVP RF, f. 5, op. I6, pap. I I2, d. I I3, 1. 23 (N.N. Krestinskii to L.M. Karakhan, May I3, I936).

30. Stephen G. Gross, Export Empire: German Soft Power in Southeastern Europe, I89o-1945 (Cambridge, 20I8). 
counter Turkish dependence on the West; in I936, the Turkish ambassador in Moscow begged his hosts to help curb Turkey's dependence on Germany. Just months after the disagreement at Montreux, Turkey again requested a loan from the Soviet Union-this time in the amount of \$IOO million worth of goods, again to be paid off with agricultural produce and to be used for industrial projects. ${ }^{32}$ Moscow's options were limited given preparations for war, but the new trade agreement signed in I 937 was an attempt to address Turkey's concerns. Soviet-Turkish trade nearly doubled that year, and did so within the net balance framework. ${ }^{33}$ From 1920 until i939, Moscow and Ankara demonstrated a remarkable commitment to bilateral relations despite geopolitical differences, most importantly on the crucial question of the Straits.

The Second World War irreversibly changed the nature of the SovietTurkish relationship because it brought back mutual hostilities like the ones which had plagued Russian-Ottoman relations. The announcement of the Nazi-Soviet Pact in 1939 put an end to the interwar convergence, for Hitler and Stalin had bargained over Eastern European territories and Ankara quickly learned that the Soviets were eyeing the Straits. Insecurity in Europe had pushed Moscow to consider taking direct action on its long-standing concerns; fear of the Soviet Union came to dominate Turkish politics. For the next two decades, Turkey sought supporters who might check Soviet aggression-first Great Britain and Nazi Germany, and later the United States. Soviet politicians, in turn, alleged that Ankara had become a pawn of imperialism, whether in its German or U.S. form. This period of open tension between Moscow and Ankara was an anomaly in the twentieth century and came to an end in the mid-I950s, but relations had been fundamentally transformed. The sharp geopolitical differences against which Moscow and Ankara had to maintain their economic cooperation after the First World War could no longer be ignored.

The Nazi-Soviet Pact ended any claim that the Soviet Union and Turkey jointly opposed more powerful and predatory states. Moscow's agreement with Berlin was economic as well as political, and the expansion of the Nazis' Eurasian trade zone to include the Soviet Union left Turkey absolutely dependent upon Germany. ${ }^{34}$ The Soviets sought to capitalize on Turkish weakness. Just six weeks after the Nazi-Soviet Pact, Soviet foreign minister Viacheslav

3I. Türkiye Cumhuriyeti Başvekalet İstatistik Umum Müdürlüğü, Harici Ticaret: Yılllk Istatistik 1936 (Ankara, I937), I 74-I75; on Germany's own anxieties about Western economic power, see Adam Tooze, The Wages of Destruction: The Making and Breaking of the Nazi Economy (London, 2006).

32. Turkish Diplomatic Archives (hereafter TDA), TSID 5032066 (Moscow Embassy to the Turkish Ministry of Foreign Affairs, December 23, 1936). The archivists at TDA stipulated that all references should be made to the document's digital identification number, or TSID.

33. Türkiye Cumhuriyeti Başvekalet İstatistik Umum Müdürlügü, Harici Ticaret: Yillık İstatistik 1937 (Ankara, I938), 42-44.

34. On the Third Reich's Eurasian trade zone, see Jennifer Jenkins, "Iran in the Nazi New Order, 1933-194I," Iranian Studies 49, no. 5 (2016): 72 I-75 I. 
Molotov met his Turkish counterpart Şükrü Saraçoğlu in Moscow to discuss a dramatically reconfigured Europe. Molotov menacingly referred to Poland's fate and repeated earlier Soviet objections to the Montreux Conference. ${ }^{35}$ Moscow's unqualified demands for changes to the Straits regime rendered impossible the previous containment of differences. Ankara's leaders now abstained from continental politics they saw characterized by imperialism on all sides. Turkey chose neutrality during the war to maintain both British and German backing against possible Soviet aggression. ${ }^{36}$ Then, when Hitler attacked the Soviet Union, it was Moscow's turn to feel betrayed. German orchestration of propaganda and pro-fascist groups in Turkey frustrated the Kremlin, but it was continued chromium sales to the Wehrmacht that truly set Moscow against Ankara. ${ }^{37}$

Without the restraining influence of the interwar partnership, Stalin's unbridled pursuit of Soviet interests pushed Turkey towards a new ally and into U.S. arms. In June I945, amidst preparations for the Potsdam Conference, the Turkish ambassador in Moscow met with Molotov. Ankara was not surprised to hear again of Moscow's dislike for the existing rules governing passage through the Straits but was shocked to be presented with a Soviet claim to much of eastern Anatolia. ${ }^{3}$ In I94I, Ankara had learned from Hitler himself of Molotov's secret proposal to establish Soviet naval bases on the Bosphorus and Moscow had openly objected to Turkish handling of the Straits since Lausanne. ${ }^{39}$ Soviet and Turkish interests did clash, and the Soviets had reason to oppose even the revised terms of the Montreux Convention because Turkey-claiming neutrality-had allowed warships from both belligerent blocs to pass into the Black Sea. Postwar Soviet demands for naval bases were the product of Moscow's conclusions about the need for absolute security; the demands for eastern Anatolia were retribution for Turkey's connections to Nazi Germany. Moscow's message suggested that previous acceptance of differences over the Straits and acquiescence to Turkish claims to eastern Anatolia in I92 I had been part of an alliance that the war had broken. When Molotov repeated Soviet conditions more assertively, Turkey begged Washington to accept that Moscow was a menace to the postwar order..$^{\circ}$

35. TDA, TSID r61936 (Moscow Embassy to the Turkish Ministry of Foreign Affairs, October 9, I939).

36. See Onur İşçi, Turkey and the Soviet Union during World War II: Diplomacy, Discord and International Relations (London, 20I9).

37. For more on the pro-Nazi and pan-Turkist groups that aroused Moscow's ire, see John M. VanderLippe, The Politics of Turkish Democracy: Ismet Inonu and the Formation of the MultiParty System (New York, 20I 2), 55-75; and Onur İşçi, "The Massigli Affair and its Context: Turkish Foreign Policy after the Molotov-Ribbentrop Pact," The fournal of Contemporary History 55, no. 2 (2020): $27 \mathrm{I}-296$.

38. TDA, TSID I6992896 (Report on the V.M. Molotov-Selim Sarper Meeting, June 9, I945).

39. TDA, TSID I I 848208 (Hüsrev Gerede to Şükrü Saraçoğlu, March I7, I94I).

40. TDA, TSID r699288 ( (Minutes of the Molotov-Sarper Meeting, June 7, I945). 
From the end of the Second World War until i957, Turkey was closer to the transatlantic West than at any other point after the founding of the Republic. While the immediate Soviet threat dissipated in 1947, Ankara came to see itself as the anchor of United States-led containment in the Middle East and beyond. Turkey's deployment of troops to the Korean War paved the way for NATO membership in 1952. Forgetting the economic aspect of Atatürk's program for transformation, many in the Republic briefly celebrated these events as the culmination of the drive to be on equal footing with the West. The repercussions for Moscow were drastic: the United States began construction of the Adana air base in I95 I and the Soviet Union now shared a direct border with a Western ally. Immediately after Stalin's death in I953, Moscow renounced the earlier Soviet demands in an attempt to improve relations with Turkey and reduce the threat on the southern border. ${ }^{4 I}$ Despite a number of Soviet overtures that were part of de-Stalinization, memory of the war years kept Turkey devoutly anti-communist for several more years.

Ankara's diplomatic pivot towards the West was connected to domestic changes that undermined the shared economic nationalism that nourished earlier Soviet-Turkish cooperation. Neutrality had not shielded Turkey's markets and in I946 Ankara devalued the lira for the first time in the history of the Republic, instituted liberal trade policies, and shed its protectionist traditions. ${ }^{42}$ Harry Truman's extension of U.S. assistance via the Marshall Plan strengthened Turkey's reorientation and encouraged political adjustments in Ankara. Adnan Menderes became the first democratically elected prime minister in 1950 , and his background as an Aegean landowner differed sharply from the older military-bureaucratic elite. Menderes's agricultural sympathies overlapped with some of the goals of the U.S. officials who accompanied aid, for the latter pushed Ankara to reject the statist industrialization of the I930s. ${ }^{43}$ Yet U.S. advisers believed that Menderes's policies, despite their ostensible free-market basis, were characterized by unproductive subsidies designed to shore up his political base. When Turkey experienced a foreign payments crisis after international wheat and cotton prices fell in I954, Menderes and his U.S. advisers fell out, and many Turks began to doubt whether the U.S. alliance could address the country's economic concerns. ${ }^{44}$

4I. BCA, 30.10.0.o/6r.376.I (Molotov's Note to the Turkish Ambassador, May 30, I953).

42. Korkut Boratav, Türkiye Iktisat Taribi, 1908-2005 (Ankara, 2006), 97-IOI.

43. Sevket Pamuk, Uneven Centuries: Economic Development of Turkey Since I82o (Princeton, NJ, 20I8), 206.

44. Memorandum of Conversation Prepared in the Bureau of Near Eastern, South Asian and African Affairs, October I4, I954, Foreign Relations of the United States (hereafter FRUS), I952I954, vol. VIII, Eastern Europe, Soviet Union, Eastern Mediterranean, eds. David M. Bachler, Evans Gerakas, Ronald D. Landa, and Charles S. Sampson (Washington, D.C., I988), doc. 490; Memorandum From the Deputy Assistant Secretary of State for Near Eastern, South Asian and African Affairs (Jernegan) to the Under Secretary of State (Hoover), February 2 I, 1955, FRUS, I955-1957, vol. XXIV, Soviet Union, Eastern Mediterranean, eds. Ronald D. Landa, Aaron D. Miller, and Charles S. Sampson (Washington, D.C., I989), doc. 3 I8. 
Tension with the United States, as had previous disagreements with the West, encouraged new contacts between Moscow and Ankara. Soviet-Turkish trade amounted to a grand total of zero between 1940 and I954 but began to pick up in the context of the post-Second World War recovery of international trade and even before significant political rapprochement had been reached. ${ }^{45} \mathrm{It}$ conformed, however, to earlier patterns. With currency short, Menderes's government was forced to reinstitute controls on foreign trade and Turkey signed a new set of clearing agreements with a handful of countries. Turkey's limited return to a barter system made the Soviet Union a natural partner and allowed Moscow to work towards the normalization of relations with Ankara. ${ }^{46}$

Before truly opening up to the Soviet Union, Menderes tried one last time to shore up the Western alliance. With his economic policies failing, he sought an easy political victory to emphasize the instrumental role he could play in the U.S. policy of containment. With Arab nationalism on the rise and the Soviet Union backing Damascus, Turkey mobilized troops along the Syrian border and sought to draw Washington into the confrontation. ${ }^{47}$ Soviet Premier Nikita Khrushchev followed with a promise to retaliate against any Turkish aggression, and the Soviet Union and Turkey seemed on the brink of war. U.S. President Dwight Eisenhower was unmoved by Ankara's maneuvers and suppressed tensions in Syria; the simultaneous refusals of Turkish requests for aid further alienated Menderes. ${ }^{8}$ The Turkish prime minister expressed frustration at a NATO summit in December 1957 in terms that forecast change in Ankara's foreign policy: he argued that NATO had made a "grave error" and spoke more broadly of disillusionment at Turkey's isolation. ${ }^{49}$ The Syrian Crisis and U.S. insistence that the Turkish government take the politically unpopular step of another devaluation of the lira suggested to Ankara the dangers of an unqualified alliance with Washington. Khrushchev's withdrawal of the territorial demands in 1953 , a general softening of the Soviet stance, and the gradual return of statist economic policies made possible Turkey's revival of economic cooperation with the Soviet Union.

From the Syrian Crisis in 1957 until the coup of 1980 , a shared desire for economic exchange defined Soviet-Turkish interstate relations. Successive

45. Sanchez-Sibony, Red Globalization, I4I; V.N. Koptevskii, Rossiia-Turtsiia: Etapy torgovoekonomicheskogo sotrudnichestva (Moscow, 2003), 4I 2.

46. "Sovyetler Birliği ile Dış Ticaretimiz," Milliyet, August I7, 1965; Koptevskii, RossiiaTurtsiia, I I 2.

47. "Central Intelligence Bulletin," August I, I957, RDP79 Too975Aoo320027000I-6, CIA Records Search Tool (CREST), U.S. National Archives, College Park, MD.

48. National Security Council Report, June 29, I957, FRUS, I955-1957, vol. XXIV, doc. 359; Cumming to the Secretary of State, August 7, I957, FRUS, 1955-1957, vol. XXIV, doc. 362; the Department of State to the Embassy in Turkey, October 20, I957, FRUS, I955-1957, vol. XXIV, doc. 367 .

49. BCA 30.0 I.0.0/I6.85.4 (Adnan Menderes's NATO Speech, December I6, I957). 
governments in Ankara- on the left and right-described their nation's "underdevelopment" as one of the most pressing problems of the day, and Soviet economists added Turkey to their lists of "developing countries." 50 Much of the language of anti-imperialism was gone, but Ankara and Moscow were united again by a vision of a world composed of haves and have-nots. Although Turkey remained a member of NATO, tension with the West-particularly over the status of Cyprus_created parallels between Ankara's foreign policy and the policies of non-aligned countries. Turkey's politics again became explicitly statist and Moscow sent engineers and machinery to build factories in a number of Anatolian towns. Just as thirty years earlier, Turkey paid off Soviet investments in figs and raisins. Cold War construction projects followed the model that isolated exchange from the global market economy and from the two states' divergent geopolitical interests. Now, however, these exchanges were ordinary. The Soviet Union's approach to Turkey drew on the history of the interwar period but it conformed to a pattern of development politics that was common to its relations with much of the Global South.

Turkish statism during the Cold War, unlike its interwar predecessor, was not overtly affiliated with the Soviet Union. As Western objections to Menderes's misuse of foreign aid mounted in the early I950s, the Organization for Economic Co-operation and Development (OECD) and the United States Agency for International Development (USAID) encouraged the Turkish government to take a more planned and self-sustaining approach to economic initiatives. ${ }^{5}{ }^{\mathrm{I}}$ By the late-I950s and I960s, the Turkish political elite accepted the need for statism but were divided over the form it should take. The militarybureaucratic old guard favored state ownership and management of industry, in part for social and political reasons; their opponents sought to limit the state's role to the encouragement of private enterprise..$^{2}$ The two sides did agree on a course of import substitution industrialization. The first major wave of Turkish postwar industrial development produced refrigerators, radios, and televisions and transformed the domestic consumer market in the r96os. Yet while local production replaced some imports, export levels remained unchanged. Turkey continued to depend on foreign intermediate products and the country faced a series of payments crises along with growing popular discontent. In these circumstances, the Soviet Union was an attractive partner for advocates of a more activist statism who supported large state-managed industry as a cure for unemployment. The largest Soviet-Turkish initiatives of the r96os and r970s-a

50. A.A. Rodionov, Turtsiia: perekrestok sudeb. Vospominaniia posla (Moscow, 2006); V. Smirnov, "Na osnove vzaimnoi vygody, $\mathrm{v}$ interesakh ukrepleniia ekonomicheskoi nezavisimosti razvivaiushchikhsia stran," Vneshniaia torgovlia I 2 (1972): 24-29.

5 I. Günal Kansu, Planl Yillar [amılarla DPT'nin öyküsï] (İstanbul, 2004), 38; Sylvia Maxfield and James H. Nolt, "Protectionism and the Internationalization of Capital: U.S. Sponsorship of Import Substitution Industrialization in the Philippines, Turkey and Argentina," International Studies Quarterly 34, no. I (I990): 49-8 I.

52. Pamuk, Uneven Centuries, 2 I 5. 
steelworks, an aluminum plant, and an oil refinery-were state-run icons of Turkey's progress towards a truly industrial modernity. Moscow's willingness to engage in interstate development and to accept payment in Turkish agricultural goods gave Ankara a way to capitalize on the social and political symbolism of development that complemented Turkey's Western-supported initiatives.

Moscow was well aware of the differences between the two major parties that dominated the Turkish political landscape in the r96os and I970s but was prepared to work with both sides. İsmet Inönü, whom Soviet observers had lauded in the I930s as a progressive force because he was the leader of Turkey's statists, still led the old guard's Republican People's Party into the I96os. Yet the Soviet Union did not favor him or his party over their conservative opponents, the Justice Party, despite believing the latter to be comprised of the "most reactionary circles" of the bourgeoisie. ${ }^{53}$ The Republican People's Party finally earned some Soviet sympathy as it moved left under Bülent Ecevit in the I970s, but even then Moscow continued to see it as a reflection of the bourgeoisie's interests and unlikely to break off Turkey's relations with NATO. ${ }^{54}$ Beginning in the I96os, the Soviet Union finally had a socialist movement in Turkey to support. The Workers' Party of Turkey received just under three percent of the vote in national elections in 1965 and socialist politicians entered the Turkish parliament. ${ }^{55}$ Despite the relative weakness of Turkey's socialists, Moscow was confident that worsening economic conditions and public opinion would force both of Turkey's bourgeois parties to cooperate with the Soviet Union. Even while Moscow signed off on shipments of industrial equipment to Turkey, the major Soviet newspapers criticized Ankara governments for increasing oppression of the leftists who Moscow hoped would ultimately triumph. ${ }^{56}$ At the height of Soviet-Turkish exchange, Moscow's politicians were convinced that Turkey's economic problems made statism all but inevitable, even if the Soviet Union did not have true ideological allies in power in Ankara.

In I957, even before the Turkish government openly embraced a return to statism, Turkey and the Soviet Union began to explore ways to push economic exchange beyond their carefully managed bilateral trade. With the conditions on Western aid tightening, Menderes sent a delegation to Moscow to negotiate Soviet investment. ${ }^{57}$ On the eve of the Syrian Crisis, Moscow appointed Nikita Ryzhov as ambassador to Ankara, and Turkish observers recognized the

53. Russian State Archive of Contemporary History (hereafter RGANI), f. 5, op. 59, d. 399, 11. 86-Io3 (Kh. Mamsurov to the International Department of the Central Committee, September 15, 1967).

54. RGANI, f. 5, op. 6I, d. 554, 11. I76-I 84 (L. Tolokonnikov to the International Department, October 3, I969); RGANI, f. 5, op. 69, d. 2609, 1l. I 5-2 I (L. Manzhosin to the International Department, May i9, I976).

55. RGANI, f. 5, op. 59, d. 399, 1l. 34-43 (V. Pokrovskii, February 27, I967).

56. RGANI, f. 5 , op. 63 , d. $60_{3}$, 1. 33 (N. Simonenko to B.N. Ponomarev, June 27, I97 I).

57. Cahit Kayra, Cumburiyet Ekonomisinin Öyküsü vol. 2 (İstanbul, 20I 3): 9I-92. 
political message-Ryzhov had worked in Kayseri during the I93os and could bear personal witness to the earlier phase of Soviet-aided industrialization. Soviet industry returned to Turkey in 1958 when Moscow successfully bid to build a glass factory in Çayırova. This project was a Soviet commercial venture and not part of an interstate development-oriented agreement, but the Soviet investment was significant: Çayırova became the second site for Turkey's largest producer of glassware for the home. Construction began in 1959, and Soviet engineers joined Turkey's consumer-focused import substitution industrialization just as Menderes accepted the deployment of U.S. intermediate-range ballistic missiles on Turkish soil. The arrival of Jupiter missiles did not spell the end of Soviet-Turkish normalization; that same year, the Turkish minister of health visited Moscow and agreed on a personal meeting between Menderes and Khrushchev. Turkish frustrations with the lack of development despite NATO membership led to Soviet-Turkish economic cooperation that trumped the political conflict of the Cold War.

A group of Turkish officers overthrew the goverment in 1960 and temporarily interrupted Soviet-Turkish rapprochement. The military leadership immediately signaled their economic preferences with the establishment of the State Planning Organization, and Moscow initially welcomed the coup. Soviet newspapers celebrated Menderes's removal and argued that his "puppet regime" had left the Turkish economy on the brink of catastrophe. ${ }^{5}$ Moscow hoped that Ankara would move further from its pro-Western stance and defense-oriented budget, but, as Menderes had done with his Syrian adventure, the post-coup military regime tried to reaffirm Turkey's commitment to the U.S. alliance. In the space of two years, Turkey was twice drawn into Soviet-U.S. conflicts: the $\mathrm{U}_{2}$ spy plane incident proved manageable, but the Cuban Missile Crisis led the United States to withdraw the Jupiter missiles that had been dispatched to Turkey just a few years earlier. Washington's failure to consult the Turkish military and growing differences over Cyprus produced sufficient frustration with the United States to push Ankara decisively towards Moscow.

Turkey's I 963 outreach to the Soviet Union was the most provocative move in a broader gambit to decrease dependence on the United States. That year, Ankara signed a treaty of association with the European Economic Community and senate president Suat Hayri Ürgüplü led a delegation of parliament members from all of Turkey's political parties to Moscow. The inclusive nature of the Turkish group signaled an attempt to develop a consensus about the need for a new phase in relations with Moscow. Ürgüplü-the first ranking Turkish statesman to visit the Soviet Union since the Second World War-used growing trade relations as an opening to discuss Cyprus. The Soviet leadership approached the Turkish visitors as they did other guests from the developing world and encouraged the Turkish delegation to appreciate Moscow's ability to

\footnotetext{
58. A. Miller, "Druzhba, poleznaia dlia obeikh stran," Krasnaia Zvezda, October 29, I960.
} 
transform territories with tours of Azerbaijan and Uzbekistan. ${ }^{59}$ At this early juncture, some of the Turkish politicians expressed open skepticism about improved relations with the Soviet Union, not because of Cold War politics but because of the Soviet demands at the end of the Second World War. ${ }^{60}$

In the next few years, most members of the Soviet and Turkish leadership crossed the Black Sea as they worked out how to bury geopolitical conflict in the name of economic cooperation. ${ }^{6 r}$ Ankara's increasing frustration with the West hastened convergence, as Cyprus-both Turkey's concerns about ethnic Turks on the island and the possibility that the Cypriot government might apply for union with Greece-formed the background for these interactions. This was especially the case after U.S. President Lyndon B. Johnson's harsh I964 letter to newly reelected Turkish Prime Minister İsmet İnönü deepened the U.S.Turkish rift. Johnson's letter upheld the geopolitical status quo and warned against a Turkish invasion of the island, but it ignored the ongoing violence between Greek and Turkish Cypriots. ${ }^{62}$ In contrast, the Soviet Union offered a clear position that addressed both geopolitical concerns and local turmoil. Moscow was not overtly pro-Turkish but insisted on Cyprus' sovereignty to prevent a Greek solution that would create another NATO bastion in the eastern Mediterranean. Nikolai Podgornyi discussed Cyprus extensively with Turkish colleagues during a 1965 visit, and Ankara celebrated two weeks later when Moscow declared support for a federal solution that recognized the bicommunal structure of the island. ${ }^{6}$ For the next decade, Turkey found useful a Soviet position that opposed maximalist Greek claims.

Compatible approaches to Cyprus and tension with the West helped, but it was economic cooperation that drove Soviet-Turkish rapprochement. On the eve of Ürgüplü's I 963 visit, Khrushchev ridiculed Turkey's alliance with the United States: he alleged that Turkey's industrial sector composed 10.5\% of the national economy when the country first accepted U.S. aid in 1948 and had only risen to $10.9 \%$ in $1960 .{ }^{64}$ As Soviet-Turkish exchange increased, Moscow continued to emphasize the cost of Turkey's military obligations. Andrei Smirnov, appointed ambassador in 1966 , lamented to his hosts that their

59. For context, see Kalinovsky, Laboratory of Socialist Development, chap. 8.

6o. RGANI, f. 5, op. 50, d. 508, 11. 59-75 (Reports on the Turkish Parliamentary Delegation's visit from Volgograd, Baku, and Tashkent, June 5, 1963).

6r. "Pust' Chernoe more ne raz'ediniaet, a soediniaet nas," Izvestiia, May 29, I963. The visits included: Feridun Cemal Erkin (I964, Turkish foreign minister); Nikolai Podgornyi (I 965 , Soviet Secretary of the Central Committee), Andrei Gromyko (1965, Soviet Minister of Foreign Affairs); Ürgüplü (for a second time, I965); Aleksei Kosygin (1966, Soviet chairman of the council of ministers); and Süleyman Demirel (1967, Turkish prime minister).

62. "President Johnson and Prime Minister Inonu: Correspondence between President Johnson and Prime Minister Inonu, June 1964, as Released by the White House, January I 5 , 1966," Middle East Fournal 20, no. 3 (1966): 386-393.

63. "Rusya'nn Tutumu Atina'da Telâş Yarattı," Milliyet, January 23, 1965.

64. M. Viktorov and M. Kovalev, "Turetskaia ekonomika v tupike," Ekonomicheskaia gazeta, October 20, 1962 . 
country had an army twice the size of West Germany's but no industry. ${ }^{65}$ Soviet-Turkish trade grew steadily in the following years, with the Soviet share of Turkish total trade peaking in 1972 at nearly seven percent. ${ }^{66}$ In one of the most revealing Turkish political documents from the period-the published diaries of Inönü's foil within the Republican People's Party-Nihat Erim recorded repeated intra-party debates about whether it was possible to maintain friendly relations with both the United States and the Soviet Union at the same time. By 1967, İnönü could argue that Turkey should ally with both Moscow and Washington, and, in case of conflict between the two, attempt to stay neutral. ${ }^{67}$ Until the 1980 coup, this strategy of balancing Washington and Moscow allowed Turkey to complement consumer-focused Western investment with industry-heavy Soviet assistance.

The real revival of Moscow's and Ankara's economic cooperation came when Turkish politicians inquired whether the Soviet Union would extend its project for Third World development and industrialization. ${ }^{68}$ Representatives of the two states signed an agreement in I 967 according to which the Soviet Union was to build seven industrial plants in Turkey. In a demonstration of the extent of Turkish support for relations with the Soviet Union, it fell to the leader of the center-right Justice Party, Süleyman Demirel, to sign and then defend this statist initiative against Turkish anti-communist critics. ${ }^{69}$ Even as Demirel pushed the State Planning Organization towards the more limited function of encouraging private enterprise, he embraced Soviet aid that allowed Turkey to generate intermediate products and employment in semi-rural areas. The Turkish government was able to negotiate a strong role for Turkish interests in the construction projects, as, for example, Turkish shipping companies transporting thousands of tons of parts from the Il'ichevsk port near Odessa across the Black Sea. ${ }^{70}$

The Soviet-built projects were privatized in the early 2000 , but until that point they were the cornerstones of Turkey's state-dominated heavy industry. The factory completed in Seydişehir in I 972 remains Turkey's only large-scale site of aluminum production. The steelworks opened in Iskenderun in 1975 is still the biggest in the country. The oil refinery built by the Soviet Union in Aliağa was the country's third and today supplies 25\% of Turkey's petroleum. Moscow also built a sulfuric acid plant in Bandirma and a lumber factory in Artvin but did not complete two intended projects that were clearly seen as less vital to state interests: the expansion of the glass factory in Çayırova and the addition of a vodka facility to the Turkish state distillery with an annual capacity

65. Nihat Erim, Günlïkler, I925-1979, vol. 2 (Istanbul, 2005): 842.

66. Koptevskii, Rossiia-Turtsiia, $4 \mathrm{I} 3$.

67. Erim, Günlïkler, 800, 849, 86r.

68. "Ürgüplü Bugün Moskova'da Kosigin'le Görüşecek," Milliyet, August 9, I965.

69. Kansu, Planl Yillar, i 72.

70. RGANI, f. 5, op. 62, d. 324, 11. I43-I 49 (M. Kovrigin to the Central Committee, August 9, I970). 
of two million liters. The Soviet-Turkish agreement came just a year after a similar Soviet-Indian agreement that entailed significant Soviet commitment to the oil and energy sectors. ${ }^{71}$ If Turkey stood out among the Soviet Union's Third World partners, it was only for the fact that Moscow did not send military aid to this NATO ally.

Moscow calculated investments to contrast with and supplant Washington's role in Turkey's development. In the spring of 1965 , the United States had declared that aid would soon end and Turkey needed to figure out sustainable development. With U.S. contributions falling, Western aid totaled \$206.6 million in 1967 , and that number fell to $\$ 155.7$ million in $1968 .^{72}$ Returning from Moscow in 1964, the Turkish foreign minister reported that the Soviets were promising that they would provide aid if the United States cut Turkey off. ${ }^{73}$ The 1967 agreement foresaw Soviet investment of \$200 million, and, while the Soviets ultimately invested even more, it can hardly have been coincidental that the figure chosen matched all Western investments for that year. The Soviet Union did not offer aid in the form of grants, but, once again, did not ask for payment in hard currency. ${ }^{74}$ The agreement adopted the interwar model and took as its formal basis the 1937 clearing agreement. Turkish payments were to be deposited in a Soviet account in the Turkish central bank, and Moscow agreed to spend all proceeds on Turkish exports, including set amounts of hazelnuts, citrus fruits, raisins, and olives. ${ }^{75}$ The Soviet investments in Turkey resembled the model of import substitution offered to other parts of the Global South: loans for state-led development of heavy industry, paid off with local exports. ${ }^{76}$ As was true across the Global South generally, the total amount of Soviet aid was ultimately a fraction of the Western equivalent, but it allowed the Turkish government to celebrate highly visible industrial projects.

The Soviet-built oil refinery and steel mill could not help Ankara solve broader structural problems, and the I970s were a troubled decade for Turkey as for much of the world. Energy prices were rising and a 1975 interstate agreement saw the Soviet Union build an electricity plant in Western Anatolia and extend a line that brought electricity from Georgia into eastern Anatolia. Nonetheless, Turkish exports were still stagnant and created repeated balance of payments crises. As the Turkish intervention on Cyprus in 1974 led to a U.S. arms embargo and international isolation, economic problems were compounded by political ones. Conflict with the West again strengthened SovietTurkish relations. For the first time since the I920s and I930s, cooperation moved into the military sphere-soon-to-be chief of staff of the Turkish Armed

71. On the Indian agreement, see Engerman, Price of Aid, 274.

72. George S. Harris, Troubled alliance: Turkish-American Problems in Historical Perspective, 1945-197I (Stanford, CA, I972), I73-180.

73. Erim, Günlïkler, 790.

74. See Sanchez-Sibony, Red Globalization, I40.

75. T.C. Resmî Gazete, June 2, I967.

76. See Iandolo, "The Rise and Fall," 685. 
Forces Kenan Evren visited the Soviet Union in 1976 , and his Soviet counterpart Nikolai Ogarkov made the return trip in April 1978. Moscow might have offered military equipment if the U.S. arms embargo had lasted long enough, but just five months after Ogarkov's Ankara trip, Washington yielded to Turkey's requests for arms. The U.S.-Soviet divide meant that economics continued to be the prime realm for Soviet-Turkish engagement.

The conflict over Turkish intervention on Cyprus was but one of many signs that the bipolar structure of Cold War international relations was giving way to a more complex and multipolar set of forces. Just as Turkey was drawn into the Soviet-U.S. struggle to develop the Third World in the I95os and r96os, so too did Turkey become a site of Soviet-Chinese competition for influence in the I $970 s .^{.77}$ In the aftermath of the Prague Spring, the Soviet embassy in Ankara began to send home regular and troubled reports about the increasing visibility of Maoist revolutionaries among the Turkish youth. ${ }^{7}$ Soviet diplomats singled out Doğu Perinçek for his anti-Soviet activities, which were, they worried, being stoked by literature supplied by the Chinese embassy in East Berlin and the Albanian embassy in Ankara. By the mid-I97os, Moscow feared that the Chinese were not only trying to turn the Turkish left against the Soviet Union but also to form a partnership with the mainstream Turkish political parties. The Soviets themselves were pursuing political influence through interstate economic relations, and hence worried as a new Chinese ambassador in Ankara, Wei Yung-Ching, proposed that Chinese organizations help Turkey explore energy resources in the Mediterranean Sea and orchestrated the delivery of Chinese industrial equipment for the textile industry in Turkey's southeast. ${ }^{79}$ The Soviet Union now saw Soviet-Turkish economic cooperation as a necessary response to both U.S. and Chinese influence in Turkey. ${ }^{8 \circ}$

Although détente had allowed the Turkish government to improve relations with opposing ideological blocs abroad, domestic leftists and rightists experienced no such easing of ideological tensions. Protests, street violence, and ideologically-driven massacres escalated in tandem with economic difficulties, and the process culminated in Turkey's most traumatic coup in 1980. Tens of thousands were arrested and several years of military rule painfully ushered in a new, less ideological era. In the aftermath of the coup, a new Turkish party jettisoned import substitution industrialization for neoliberal consumerism.

77. On Sino-Soviet competition, see Jeremy Friedman's Shadow Cold War: The Sino-Soviet Competition for the Third World (Chapel Hill, NC, 2015); on Turkey's place in that story, see Çağdaş Üngör, "China and Turkish Public Opinion during the Cold War: The Case of Cultural Revolution (1966-1969)," in Turkey in the Cold War: Ideology and Culture, ed. Cangül Örnek and Çăgdaş Üngör (Houndmills, 20I3), 47-66.

78. RGANI, f. 5 , op. 63 , d. 603, ll. I 7-24 (V. Grubiakov to the Soviet Foreign Ministry, June 9, I97I).

79. RGANI, f. 5, op. 69 , d. 2609 , 11. 64-68 (A. Kasymov to the International Department, August 19, 1976).

8o. For an explicit statement of this idea, see RGANI, f. 5, op. 63, d. 603, 1. 22 (I. Lakomskii to the International Department, June 9, I97I). 
Moscow and Ankara continued the economic cooperation that they had achieved in the previous period, but they gradually left behind the geopolitical divisions and development politics of the Cold War.

The Soviet Union's collapse has made it easier to see that, already by the I980s, Turkey viewed its northern neighbor less in the framework of the Cold War and more as coinhabitant of a shared geographic space. Ideological figures from both sides of the Black Sea-prominent among them Aleksandr Dugin and Doğu Perinçek-noted this in the I99os when they began to speak of "Eurasia." Perinçek's earlier Maoist politics had been transformed by a lengthy jail term and the collapse of the Soviet Union; he now found anti-American allies in Russia, and for Dugin and Perinçek Eurasia had distinctly anti-Western connotations. ${ }^{81}$ Academics across the world now also employ the term "Eurasia," albeit with less political baggage, to designate an area that is neither Western nor European and includes Russia and Turkey. In the I980s, however, economic change rather than ideology remade the region.

The Soviet and Turkish political elites of the 198 os were increasingly aware of their own economic weaknesses and the limits of their statist industrial development. A new interconnectedness emerged from separate but similar processes of transformation that began first in Turkey and slightly later in the Soviet Union, as economic liberalization entailed greater openness towards the West. Freer markets attracted non-state actors and what had been a bilateral and statist axis became a complex web of exchange. Unmanaged, conflict returned. Russia's focus shrank and Turkey's expanded: Turks' direct access to peoples in the Caucasus and Central Asia with whom they shared historical connections contributed to tension with Moscow. The ig8os and i 99 os thus replaced the Cold War with regional dynamics.

Sakıp Sabancı-one of several Turkish tycoons with whom the Soviet ambassador met in the late 1970s-signaled the new era that was to come when he complained that Soviet-Turkish exchange had previously occurred solely between states and requested opportunities for private business. ${ }^{82}$ The Soviet Union's transition from an industry- to an oil-exporting economy had Moscow also thinking more firmly in terms of benefits to be drawn from Turkey. When, for example, prime minister Bülent Ecevit asked Moscow to increase oil exports to Turkey in 1978 , the Soviets agreed in principle but indicated that Ankara would need to pay with goods other than figs and raisins. The Soviets were not yet asking for hard currency but wanted more useful shipments of wool and

grain. ${ }^{83}$ Ultimately, Ankara and Moscow agreed in 1982 that exchange would

81. Stephen Kotkin, "Mongol Commonwealth? Exchange and Governance across the PostMongol Space," Kritika: Explorations in Russian and Eurasian History, 8, no. 3 (2007): 487-53 I.

82. Rodionov, Turtsiia, 96-97. 
henceforth be in freely traded currencies. ${ }^{84}$ And yet, two years later when Moscow and Ankara negotiated the opening of the first pipeline that would bring natural gas from the Soviet Union to Turkey, Ankara succeeded in persuading Moscow to spend revenue on Turkish exports. ${ }^{85}$ Turkey's increasing imports of Soviet energy threatened to undermine the principle of net balance that had characterized bilateral trade, and the Soviet agreement to accept payment in Turkish goods was a concession to allow Ankara to protect currency reserves. It took a full seven years after the collapse of the Soviet Union for Moscow to persuade Turkish companies to finally pay for Russian energy in hard currency.

As much as the old practices proved hard to break, state-sponsored projects decreased in number and private enterprise reshaped traffic across the Black Sea. Even here, though, the two states had their hands in what looked like free trade. In 1986, Turgut Özal, prime minister and the face of his country's neoliberal turn, traveled to Moscow and lobbied for Turkish access to Soviet construction projects; in 1987 , an interstate agreement stipulated that thirty percent of Soviet revenue from gas sales to Turkey would be transferred to Turkish companies for projects to be realized in the Soviet Union. ${ }^{86}$ This agreement facilitated the Turkish company Enka's first major foray north-the renovation of the prestigious Petrovsky Passage, just down the street from the Kremlin. Meanwhile, tourists from the former Soviet Union traveled in the opposite direction and produced a vibrant "shuttle trade." What began as small-scale commerce between Turkish shopkeepers in Black Sea bazaars and post-Soviet "tourists" grew to an estimated annual volume of ten billion dollars by the midI99os. ${ }^{87}$ Although Ankara's official statistics showed a trade deficit that ballooned with the transition from planned economy to neoliberalism-in part because of increasing imports of Russian gas and oil-the current account deficit was stabilized by hard currency that entered the Turkish economy in suitcases. The most prominent elements of free market trade in the r 980 s and I99os thus fit into a framework that balanced Turkey's imports from the former Soviet Union.

These economic ties expanded and diversified despite the concurrent intensification of Russian-Turkish competition in Eurasia. After the Soviet Union collapsed, Turkey sought to become a model for the new states in the Caucasus and Central Asia. Ankara's politicians played big brother in a self-appointed mission to translate Western development for what they called "the Turkic

83. Rodionov, Turtsiia, I 55 .

84. B. Rudnev, "Sovetsko-Turetskaia Torgovlia," Vneshniaia torgovlia 8 (I986): I6; V. Kostikov and V. Litvinov, "Polveka dogovoru o torgovle i moreplavanii mezhdu Sovetskim Soiuzom i Turtsiei," Vneshniaia torgovlia I I (1987): 49-50.

85. Koptevskii, Rossiia-Turtsiia, r6 I.

86. Mehmet Ali Birand, "Rusya'da Bir Şeyler Oluyor," Milliyet, January 31, I987.

87. M. Eder, A. Yakovlev, A. Çarkoğlu, "Suitcase Trade Between Turkey and Russia: Microeconomics and Institutional Structure," Sotsiologiia Rynkov (2003): I-28. 
world" and hoped to become the Brussels of a Central Asian union. Equally, engagement with Eurasia was an attempt to reformulate Turkey's strategic value for the Western alliance. The inauguration of the Turkish International Development and Cooperation Agency (TIKA) in 1992 attested to Turkey's desire to institutionalize its role as a bridge between West and East. Moscow worried that not only was Turkey a conduit for Western influence but also that Ankara sought the erosion of Russian authority in the region. The Muslimpopulated North Caucasus had a history of Ottoman-backed defiance, and Moscow accused Ankara of returning to pre-First World War patterns by providing covert aid to separatists during the wars in Chechnya. Russia responded by supporting the Kurdistan Workers' Party (PKK), which was involved in an equally violent battle against the Turkish state. The Chechen and Kurdish conflicts became the crux of the two states' problems in the I990s and the crisis reached its climax in 1996. A group of Chechens and Turkish nationals hijacked a Sochi-bound ferry in Trabzon and threatened to execute the Russian nationals on board. The Kremlin retaliated by providing brief sanctuary for Abdullah Öcalan-leader of the PKK—while he was on the run in 1998. The name of the ferry seized in Trabzon was Eurasia (Avrasya) and it provided a fitting symbol of the way that shared geography divided Moscow and Ankara.

Greater integration into global markets made both countries more vulnera-

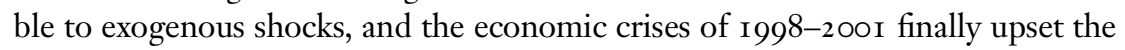
delicate equilibrium. Even as bilateral trade had increased nearly threefold in the last decade of the twentieth century, and despite Russia's energy sales, the trade balance remained relatively even. Despite competition in the Caucasus and in Central Asia, in 1997 the two states finalized an agreement on a new pipeline to bring even more Russian gas directly to Turkey underneath the Black Sea. 1998 changed all this, as economic crisis undermined Russia's ability to purchase Turkish goods and construction services to offset energy sales. ${ }^{88}$ Turkey's own crisis followed in 200I. External factors took more of the blame than reckless financing and poor debt management, and, as Moscow and Ankara concluded that radical pro-Western liberalization could not produce an answer to either country's economic problems, the two began to return to the pattern of interstate cooperation that has been so prevalent in the past century.

$* * *$

Had the Soviet-Turkish economic cooperation of the I96os and I970s ended decisively with the liberalization of the 1980 os or dwindled slowly until the shocks of the late I990s, the factories in İskenderun and Seydişehir could be seen as a Cold War development story with an unusual interwar prelude. But post-Soviet Russia's and Turkey's renewed commitments to ambitious interstate projects point to the persistence of that older pursuit of parity with the West.

88. Koptevskii, Rossiia-Turtsiia, 4I4. The data is also available via the Turkish Statistical Institute, though the website does not generate precise hyperlinks to individual search results: http://www.tuik.gov.tr/. 
Turkish President Recep Tayyip Erdoğan and Russian President Vladimir Putin forged very different paths out of the economic crises of I998-200 I only to be gradually united by overlapping frustrations with the international order. Erdoğan's initial commitment to European Union membership relied on institutional connections with the West that were significantly deeper in Turkey than in Russia; Putin's priorities-the reassertion of state authority and the subordination of oligarchs who had emerged in the free-wheeling I990s-were domestic. Yet both leaders achieved economic growth in the 2000 s that produced loyalist billionaires and more assertive foreign policies. As their power has grown, both Erdoğan and Putin have reclaimed for their states some of the prerogatives that were surrendered at the end of the twentieth century. Western observers were quick to see Russian and Turkish actions in former imperial spaces as part of a return to Tsarist and Ottoman traditions, and the monotony of Western accusations of corruption and violations of rule of law have allowed Erdoğan and Putin to build narratives of Western hypocrisy that play well among their bases. Erdoğan argues that the European Union betrayed him, much as Putin argues that NATO expansion into Eastern Europe violated postCold War promises. The collapse of the Soviet Union allowed for the reemergence of a hegemonic Western order that, as in the I 920 , has made frustration with the West the basis of the Russian-Turkish joint commitment to economic development.

Two decades into the twenty-first century, Moscow's and Ankara's political systems have for the first time obtained real ideological likeness. The governments led by Putin and Erdoğan use majoritarian approaches to democracy as a weapon to centralize power and silence opposition, and at moments the leaders have expressed mutual admiration. Yet regime similarities can only partly explain exchange that builds on the patterns of the previous century.

As before, economic cooperation persists despite numerous conflicts of interest-Moscow and Ankara have had to suppress the issues that divided them in the I 980 and I99os. Bankruptcy and default helped reduce direct competition: Turkey declined to host the World Chechen Congress in 2002 and Russia gradually curtailed its support for the PKK. But Moscow's rejoicing was short-lived in 2003 when the Turkish parliament's refusal to join the U.S.-led invasion of Iraq seemed to suggest that Ankara was beginning to stake out an autonomous path. NATO successfully pressured Ankara for access to the Straits during the Russian-Georgian conflict in 2008, and the Washington-led opposition to Turkey's purchase of Russian S-400 anti-aircraft weaponry in 2018-2019 points to the difficulties associated with any Turkish attempt to balance ties with Russia and the West. Yet outside the military sphere, Turkey has more flexibility. When Moscow incorporated Crimea into the Russian Federation in 20I4, Turkey-despite widespread expectations that Erdoğan would denounce the move in support of Crimean Tatars and in line with most Western statesremained silent. The protests Turkey has made have not been coordinated with the West. Echoes of the interwar period are strong. Moscow's and Ankara's 
primary commitments continue to be elsewhere and make a full-fledged alliance unlikely, but Erdoğan and Putin have returned the two countries to the earlier mode of burying geopolitical differences for the sake of economic exchange.

The civil war in Syria has threatened to be an exception. Its internationalization drew Moscow and Ankara into a conflagration whose ramifications seem to be more far-reaching than anything since the hostilities of the Second World War. Ankara's enthusiasm for the Arab Spring translated into initial insistence on regime change, while Moscow's historic ties to the Syrian state led to an unequivocal defense of Syrian sovereignty. Turkey repeatedly warned Russia about incursions into national airspace, and Moscow and Ankara were on a collision course that resulted in the 2015 downing of a Russian jet. The 2016 assassination of the Russian ambassador in Ankara was less predictable, but Andrei Karlov's death exposed the strength of some factions' opposition to RussianTurkish convergence. Despite events that had many in Ankara and Washington anticipating doomsday scenarios, Russia and Turkey, together with Iran, have met regularly to negotiate an end to the violence in Syria. The Sochi summits between 2017 and 2019 attest to aspirations to arrive at a local solution free of Western interference. The management of confrontation in Syria belies any narrative of historical enmity, for again Russia and Turkey have demonstrated that unrestrained hostility is an anomaly in their modern bilateral relations.

More than anything else, it is a revived and shared commitment to state-led economic development that undergirds the rapprochement between Erdoğan's Turkey and Putin's Russia. Turkish imports from Russia run to roughly twenty billion dollars annually, more than from any other country. The TurkStream pipeline, whose construction between 2014 and 2018 halted only temporarily after the downing of the Russian jet, was one more step in Ankara's acceptance of dependence on Russian energy. Putin traveled to Istanbul for the pipeline's opening, and the frequency of high-level state visits devoted to economic cooperation has matched the exchanges of the I930s and the I96os. Since Russia's inability to buy Turkish exports during the financial collapse of 1998 undermined the principle of balanced trade, ever-rising energy imports generate a trade imbalance that concerns Turkey. But Turkey is no longer dependent on the sale of agricultural produce to offset imports from Russia. Numerous Turkish construction companies work in Russia, the largest among them Renaissance Holding. Renaissance built the Lakhta Center in St. Petersburg and the Federation Tower in Moscow City - the two tallest buildings in Europe. Turkey's economic growth has reversed some of the previous patterns: Siş̧ecam, the state-founded Turkish glass company whose operations were dramatically expanded in the late I95os with the opening of the Soviet-built factory in Çayırova, moved into the post-Soviet market in 2000 and now operates five factories in Russia. Russian economic recovery led to investments in the late 2000 s that revived the processes of the I96os-Magnitogorsk Metallurgical Company completed a new steelworks in İskenderun in $20 \mathrm{II}$, just a few kilometers from the factory built by the Soviet state. The barter system that existed 
from the I 920 until the I 980 is gone, but Erdoğan and Putin have repeatedly spoken about the need to move Russian-Turkish trade off the dollar and into local currencies. ${ }^{89}$ They echo the older model that seeks the exchange of local resources independent of international markets.

The apogee of today's Russian-Turkish economic development-the nuclear power station under construction in Akkuyu-offers the clearest evidence of the past century's patterns. If completed, Akkuyu will be a Russian-owned hamlet on the Mediterranean and is very much in the tradition of joint enterprises. The 2010 agreement signed between the Russian Federation and the Turkish Republic stipulates that the Russian side will own a minimum of $51 \%$ of the shares of the plant for the entirety of its existence..$^{\circ}$ As with previous projects, the terms of payment for Turkey are generous. Ankara pays nothing until the electricity arrives and then pays through a guaranteed purchase of set quantities from each of the reactors over the course of fifteen years. Moscow's promotion of the project highlights the idea that Russia is committed to Turkey's development-Moscow is obliged to involve Turkish companies heavily in the supply chain and to train Turkish students free of charge to work at the completed plant. ${ }^{\text {II }}$ The factories the Soviet Union built in the 1960s and 1970s struggled to be profitable, and the complicated terms of Akkuyu's construction and financing promise to make cooperation contentious. ${ }^{92}$ But cement has been laid for a project that will bind the two states for years.

For much of the world, disillusionment in the I970s and then the end of the Cold War consigned the politics of development to history. ${ }^{93}$ Yet the Russian Federation maintains a Ministry of Economic Development and the party that has governed Turkey for the past seventeen years bears the word development in its name. Post-Soviet Moscow has shed many of the former ideological ambitions that imagined a non-capitalist model of development, but a Turkey less dependent on the West carries strategic benefits-a sympathetic force within NATO in a crucial geopolitical position. For Turkey, Russia is a supplier of energy and industrial goods that entertains appeals to a past history of mutually beneficial economic exchange. As for the past century, the quest for development in the sense of the pursuit of parity with the West continues to provide a consistent framework for Moscow's and Ankara's joint projects. Much more so than the memories of imperial hostilities, the Moscow skyline and Anatolia's smokestacks offer a guide to these states' priorities.

89. "Otnosheniia s Turtsiei prinimaiut prezhnii tovarooborot," Kommersant, December 2, 20r6; "Türkiye, İlk Kez Rusya'dan Ruble ile Buğday Alacak," Cumburiyet, October 2, 20 I8.

90. T.C. Resmî Gazete, October 6, 2010.

9r. Svetlana Burmistrova, "Erdogan i Putin zapustili stroitel'stvo AES 'Akkuyu' v Turtsii," RBK, April 3, 2018.

92. Rodionov, Turtsiia, 57 .

93. Cullather, "Development? It's History." 
Now that historians have begun to study development as a historically specific phenomenon, they have firmly associated the idea's origins with European rule in non-European colonies. ${ }^{94}$ The U.S.-Soviet struggle in the global Cold War helps to explain why Washington and Moscow adopted development politics in places vacated by the European empires even as they challenged the political basis of colonial rule. ${ }^{95}$ And yet, in contrast to the global projects of the European empires and the anti-imperialist superpowers, the Russian and Turkish elites stand out for their early and consistent use of state power to impose dramatic transformation on their own populations. ${ }^{96}$

The domestic targets of Russian and Turkish statists has not, however, meant that their drives for development were more parochial than imperial, Cold War programs. As this article has shown, not only did Russian and Turkish elites employ similar policies, those policies were frequently interconnected. For European colonial officials, development was a promise to work towards the eradication of disparity between metropoles and colonies. A related but distinct logic of overcoming relative under-development has defined Russian-Turkish interactions since the First World War. Although the dramatic flare-ups of the older geopolitical conflicts have often overshadowed this cooperation, these two historical rivals were repeatedly driven together by frustration with the Western-led international order. The history of Soviet-built industrial plants in Turkey in the name of challenging Western superiority demonstrates why we cannot limit our understanding of development to the Cold War struggle for the Third World. Russian-Turkish relations from the First World War to the present highlight the persistence of a drive for economic development that emerged as a response to Western power.

94. Stephen J. Macekura and Erez Manela, "Introduction," in The Development Century, ed. Macekura and Manela, I-2; Engerman, The Price of Aid, 4; Frederick Cooper, "Writing the History of Development," Fournal of Modern European History 8, no. I (2010): 5-23.

95. Westad, Global Cold War.

96. See, for example, Engerman, The Price of Aid, 4-5. 